\title{
Ethnic group differences in low birthweight of live singletons in Singapore, 1981-3
}

\author{
KENNETH HUGHES, NALLA R TAN, AND KWOK-CHAN LUN \\ From the Department of Social Medicine and Public Health, Faculty of Medicine, National University of
} Singapore, National University Hospital, Lower Kent Ridge Road, Singapore 0511

SUMmARY All singleton live births occurring in Singapore in the three years 1981-3 were computed, and birthweight was examined in the different ethnic groups (Chinese, Malay, and Indian). Overall the proportions of babies of very low birthweight (less than $1500 \mathrm{~g}$ ) and low birthweight (less than $2500 \mathrm{~g}$ ) were: Chinese $0.3 \%$ and $6.1 \%$, Malays $0.4 \%$ and $8.5 \%$, and Indians $0.5 \%$ and $10.0 \%$. The important finding was that in all gestational periods and virtually all maternal age and live birth order groups Indians had the highest proportion of very low and low birthweight babies. However for prematurity Indians at $6.7 \%$ had a higher rate than Chinese (5.1\%) but lower than Malays $(9.9 \%)$. Likewise for neonatal mortality Indians at 8.7 per 1000 live births were between Chinese (7.1) an 9 Malays $(9 \cdot 1)$. The evidence seems to indicate that the reason for Indians having a higher proportion of low birthweight babies is partly ethnic/genetic, and the cut-off point of $2500 \mathrm{~g}$ should perhaps be lowered for babies from the Indian subcontinent when international comparisons are being madeo

There are worldwide variations in the proportions of live births that are of low birthweight. ${ }^{1}$ In particular, there are known to be very high proportions in India, ${ }^{2}$ and it has been suggested that this may to some extent be for ethnic/genetic reasons. ${ }^{3}$ There is also some indication that low weight babies are less common in some Chinese populations. ${ }^{4}$

In a previous article we described low birthweight in Singapore in a sample of singleton births between 1967 and $1974 .^{5}$ An important finding to come out of this study was that Indians had smaller babies with a higher proportion of low birthweight babies than Chinese and Malays. The conclusion was that this difference was to some extent probably of ethnic/ genetic origin.

In the last few years birthweight in grams and basic demographic and biological information have been recorded centrally on all births in Singapore. This geographically defined population study therefore looks at all singleton live births for the years 1981-3, examining low birthweight by ethnic group. Hence it will be possible to see if ethnic group differences found in our previous study hold for recent years and after removing sampling variation.

\section{Materials and methods}

Data for all births occurring in the years 1981-3 were obtained from the Singapore Registry of Births and
Deaths and processed at the National University of $\omega$ Singapore Computer Centre using the SPSS statistica package. Births must by law be registered, and the registration of births is considered to be virtually complete as the birth certificate is an importanf document for a number of adminstrative purposes.

For the analysis the ethnic group of the father is used, but the majority of marriages in Singapore are still within the same ethnic group. For example, in 1982 for live births where the mother was Chinese, in $\mathbf{9 7 . 7 \%}$ of cases the father was also Chinese while for Malays the proportion was $\mathbf{8 8 . 3 \%}$ and for Indians $83.6 \%{ }^{6}$

Gestation obviously has a strong bearing on birthweight. Hence the data include analysis by period of gestation which refers to the number of completed weeks the baby was in the mother's womb before birth and is calculated from the first day of the last normal menstrual period. Mother's age and previous pregnancies also influence birthweight, as shown in the 1973 international study by the World Health Organization, ${ }^{7}$ and births are also analysed by these variables. Live birth order is recorded in Singapore rather than parity.

Birthweight distributions are according to the Ninth Revision of the International Classification of Diseases (ICD 9), ${ }^{8}$ which was implemented in Singapore in 1979. This defines low birthweight as less than $2500 \mathrm{~g}$, and birthweight groupings in the form 
less than $1000 \mathrm{~g}, 1000 \mathrm{~g}$ or over but less than $1500 \mathrm{~g}$, and so on. Very low birthweight is less than $1500 \mathrm{~g}$. A live birth is according to the WHO definition. ${ }^{8}$

For the analysis, the live births of 1981,1982 , and 1983 were computed together in order to increase the number of Indian births which are only about $7 \%$ of the total. The total number of live singleton births for the three years combined was 139438 with 131764 in the three main ethnic groups, of which 125189 $(95.0 \%)$ had complete social and biological information recorded and were used in the analysis. Of these, 93186 (74.4\%) were Chinese, 22390 (17.9\%) Malay, and $9613(7.7 \%)$ Indian. As was to be expected, the male: female ratio was very similar in the ethnic groups, being 1.09 in Chinese and 1.07 in both Malays and Indians.

\section{Results}

Table 1 shows the distribution of births by low birthweight both overall and by ethnic group. It can be seen that overall the proportions of very low birthweight (less than $1500 \mathrm{~g}$ ) and low birthweight (less than $2500 \mathrm{~g}$ ) are $0.3 \%$ and $6.8 \%$. By ethnic group the lowest proportions are in the Chinese $(0.3 \%$ and $6.1 \%)$ then the Malays $(0.4 \%$ and $8.5 \%)$, Indians having the highest proportions $(0.5 \%$ and $10.0 \%)$.

Table 1 Low birthweight of live singletons in the ethnic groups of Singapore, 1981-3

\begin{tabular}{|c|c|c|c|c|c|c|c|}
\hline \multirow[b]{2}{*}{$\begin{array}{l}\text { Ethnic } \\
\text { group }\end{array}$} & \multirow[b]{2}{*}{$\begin{array}{l}\text { Total } \\
\text { births }\end{array}$} & \multicolumn{6}{|c|}{ Birthweight $(\mathrm{g}) \%$} \\
\hline & & $\begin{array}{l}\text { Under } \\
1000\end{array}$ & $\begin{array}{l}1000 \\
1499\end{array}$ & $\begin{array}{l}1500 \\
1999\end{array}$ & $\begin{array}{l}2000- \\
2499\end{array}$ & $\begin{array}{l}\text { Under } \\
1500\end{array}$ & $\begin{array}{l}\text { Under } \\
2500\end{array}$ \\
\hline Chinese & 93186 & 0.1 & 0.2 & 0.7 & $5 \cdot 1$ & 0.3 & $6 \cdot 1$ \\
\hline Malay & 22390 & 0.1 & $0 . \overline{3}$ & $1 \cdot 1$ & 6.9 & 0.4 & 8.5 \\
\hline Indian & 9613 & 0.1 & 0.4 & $1 \cdot 2$ & 8.3 & 0.5 & 10.0 \\
\hline Total & 125189 & 0.1 & 0.2 & 0.8 & 5.6 & 0.3 & 6.8 \\
\hline
\end{tabular}

From Table 2 it can be seen that the proportion of term babies (37-41 weeks) is highest in Chinese followed closely by Indians and then Malays, with rates of prematuritiy (36 and under weeks) highest in Malays (9.9\%), then Indians (6.7\%) and then Chinese $(5 \cdot 1 \%)$. All ethnic groups show the expected declining proportion of very low and low birthweight births as gestational age goes from pre-term to term. For pre-term babies Malays have the lowest proportion of very low birthweight $(3.8 \%)$ and Indians the highest $(6.0 \%)$. Similarly, for low birthweight, Malays are $30.0 \%$ with Indians $42.5 \%$. For term babies (37-41 weeks) and post-term babies (42 and over weeks) Chinese have the lowest rates for low birthweight $(4.3 \%$ and $3.1 \%)$ and Indians the highest $(7.4 \%$ and $12 \cdot 1 \%)$.

Table 3 shows analysis of birthweight by age of mother. The distribution of births shows that Malays have the highest proportion of younger mothers and Chinese of older mothers. The incidence of low birthweight falls progressively with increasing age of mother before rising again with older women ( 35 years and over), though the rates for these mothers do not reach those for teenage mothers; in all three ethnic groups, the lowest rate is in the age group 30-34 years (though for Chinese and Malays this is the same as for the 25-29 age group). Table 3 also shows that for very low birthweight, Indians have the largest proportions in all maternal age groups, the difference being greatest in the youngest mothers. For low birthweight the pattern is nearly consistent within all maternal age groups, Chinese having the lowest rates, then Malays, and Indians the highest rates. The only exception is older women ( 35 years and over) where Malays have a greater proportion than Indians.

Table 4 shows that likewise for the majority of live birth order groups Indians have the highest proportion of very low birthweight babies. For live birth order up to 3 , Indians again have the highest

Table 2 Low birthweight of live singletons by length of gestation in the ethnic groups of Singapore, 1981-3

\begin{tabular}{|c|c|c|c|c|c|c|c|c|c|}
\hline \multirow[b]{2}{*}{$\begin{array}{l}\text { Gestation period } \\
\text { (weeks) }\end{array}$} & \multirow[b]{2}{*}{ Ethnic group } & \multicolumn{2}{|l|}{ Births } & \multicolumn{6}{|c|}{ Birthweight (g)\% } \\
\hline & & No. & $(\%)$ & $\begin{array}{l}\text { Under } \\
1000\end{array}$ & $\begin{array}{l}1000 \\
1499\end{array}$ & $\begin{array}{l}1500 \\
1999\end{array}$ & $\begin{array}{l}2000 \\
2499\end{array}$ & $\begin{array}{l}\text { Under } \\
1500\end{array}$ & $\begin{array}{l}\text { Under } \\
2500\end{array}$ \\
\hline $\begin{array}{l}36 \text { and } \\
\text { under } \\
\text { (pre-term) }\end{array}$ & $\begin{array}{l}\text { Chinese } \\
\text { Malay } \\
\text { Indian }\end{array}$ & $\begin{array}{r}4782 \\
2225 \\
647\end{array}$ & $\begin{array}{l}(5 \cdot 1) \\
(9 \cdot 9) \\
(6 \cdot 7)\end{array}$ & $\begin{array}{l}1.4 \\
0.8 \\
1.7\end{array}$ & $\begin{array}{l}3 \cdot 8 \\
3 \cdot 0 \\
4 \cdot 3\end{array}$ & $\begin{array}{r}9 \cdot 5 \\
7 \cdot 5 \\
10 \cdot 4\end{array}$ & $\begin{array}{l}25 \cdot 1 \\
18 \cdot 7 \\
26 \cdot 1\end{array}$ & $\begin{array}{l}5 \cdot 2 \\
3 \cdot 8 \\
6 \cdot 0\end{array}$ & $\begin{array}{l}39 \cdot 8 \\
30 \cdot 0 \\
42 \cdot 5\end{array}$ \\
\hline $\begin{array}{l}37-41 \\
(\text { term) }\end{array}$ & $\begin{array}{l}\text { Chinese } \\
\text { Malay } \\
\text { Indian }\end{array}$ & $\begin{array}{r}84466 \\
19176 \\
8618\end{array}$ & $\begin{array}{l}(90 \cdot 6) \\
(85 \cdot 6) \\
(89 \cdot 6)\end{array}$ & $\begin{array}{l}0 \\
0 \\
-\end{array}$ & $\begin{array}{l}0 \\
0 \\
0 \cdot 1\end{array}$ & $\begin{array}{l}0.2 \\
0.4 \\
0.4\end{array}$ & $\begin{array}{l}4.0 \\
5.6 \\
6.9\end{array}$ & $\begin{array}{l}0 \\
0 \\
0.1\end{array}$ & $\begin{array}{l}4 \cdot 3 \\
6 \cdot 1 \\
7 \cdot 4\end{array}$ \\
\hline $\begin{array}{l}42 \text { and over } \\
\text { (post-term) }\end{array}$ & $\begin{array}{l}\text { Chinese } \\
\text { Malay } \\
\text { Indian }\end{array}$ & $\begin{array}{r}3938 \\
989 \\
348\end{array}$ & $\begin{array}{l}(4 \cdot 2) \\
(4 \cdot 4) \\
(3 \cdot 6)\end{array}$ & $\begin{array}{l}- \\
-\end{array}$ & $\begin{array}{l}0 \\
0 \cdot 1 \\
-\end{array}$ & $\begin{array}{l}0.4 \\
0.2 \\
2.6\end{array}$ & $\begin{array}{l}2 \cdot 7 \\
6 \cdot 0 \\
9 \cdot 5\end{array}$ & $\begin{array}{l}0 \\
0 \cdot 1 \\
-\end{array}$ & $\begin{array}{r}3 \cdot 1 \\
6 \cdot 3 \\
12 \cdot 1\end{array}$ \\
\hline
\end{tabular}

= no births; $0=$ less than $0 \cdot 1 \%$ 
Table 3 Low birthweight of live singletons by age of mother in the ethnic groups of Singapore, 1981-3

\begin{tabular}{|c|c|c|c|c|c|c|c|c|c|}
\hline \multirow[b]{2}{*}{$\begin{array}{l}\text { Age of mother } \\
\text { (years) }\end{array}$} & \multirow[b]{2}{*}{ Ethnic group } & \multicolumn{2}{|l|}{ Births } & \multicolumn{6}{|c|}{ Birthweight (g)\% } \\
\hline & & No. & $(\%)$ & $\begin{array}{l}\text { Under } \\
1000\end{array}$ & $\begin{array}{l}1000- \\
1499\end{array}$ & $\begin{array}{l}1500- \\
1999\end{array}$ & $\begin{array}{l}2000- \\
2499\end{array}$ & $\begin{array}{l}\text { Under } \\
1500\end{array}$ & $\begin{array}{l}\text { Under } \\
2500\end{array}$ \\
\hline Under 20 & $\begin{array}{l}\text { Chinese } \\
\text { Malay } \\
\text { Indian }\end{array}$ & $\begin{array}{r}2233 \\
1395 \\
441\end{array}$ & $\begin{array}{l}(2 \cdot 4) \\
(6 \cdot 2) \\
(4 \cdot 6)\end{array}$ & $\begin{array}{l}0.2 \\
0.1 \\
0.2\end{array}$ & $\begin{array}{l}0.4 \\
1.0 \\
0.8\end{array}$ & $\begin{array}{l}1.6 \\
2.0 \\
1.4\end{array}$ & $\begin{array}{r}8 \cdot 2 \\
11 \cdot 1 \\
13 \cdot 8\end{array}$ & $\begin{array}{l}0.5 \\
1.0 \\
1.6\end{array}$ & $\begin{array}{l}10 \cdot 3 \\
14 \cdot 1 \\
16 \cdot 8\end{array}$ \\
\hline $20-24$ & $\begin{array}{l}\text { Chinese } \\
\text { Malay } \\
\text { Indian }\end{array}$ & $\begin{array}{r}21812 \\
8189 \\
3231\end{array}$ & $\begin{array}{l}(23 \cdot 4) \\
(36 \cdot 6) \\
(33 \cdot 6)\end{array}$ & $\begin{array}{l}0.1 \\
0.1 \\
0.1\end{array}$ & $\begin{array}{l}0.2 \\
0.4 \\
0.5\end{array}$ & $\begin{array}{l}0.7 \\
1.1 \\
1.5\end{array}$ & $\begin{array}{l}5 \cdot 4 \\
7 \cdot 6 \\
9 \cdot 3\end{array}$ & $\begin{array}{l}0.1 \\
0.4 \\
0.5\end{array}$ & $\begin{array}{r}6 \cdot 4 \\
9 \cdot 1 \\
11 \cdot 3\end{array}$ \\
\hline $25-29$ & $\begin{array}{l}\text { Chinese } \\
\text { Malay } \\
\text { Indian }\end{array}$ & $\begin{array}{r}41357 \\
7885 \\
3848\end{array}$ & $\begin{array}{l}(44 \cdot 4) \\
(35 \cdot 2) \\
(40 \cdot 0)\end{array}$ & $\begin{array}{l}0.1 \\
0.2 \\
0.1\end{array}$ & $\begin{array}{l}0.2 \\
0.2 \\
0.3\end{array}$ & $\begin{array}{l}0.6 \\
0.9 \\
1.0\end{array}$ & $\begin{array}{l}4.9 \\
5.9 \\
7.9\end{array}$ & $\begin{array}{l}0.3 \\
0.4 \\
0.4\end{array}$ & $\begin{array}{l}5 \cdot 8 \\
7 \cdot 2 \\
9 \cdot 3\end{array}$ \\
\hline $30-34$ & $\begin{array}{l}\text { Chinese } \\
\text { Malay } \\
\text { Indian }\end{array}$ & $\begin{array}{r}22172 \\
3609 \\
1703\end{array}$ & $\begin{array}{l}(23 \cdot 8) \\
(16 \cdot 1) \\
(17 \cdot 7)\end{array}$ & $\begin{array}{l}0.1 \\
0.1 \\
0.3\end{array}$ & $\begin{array}{l}0.2 \\
0.3 \\
0.2\end{array}$ & $\begin{array}{l}0.8 \\
1 \cdot 2 \\
1 \cdot 1\end{array}$ & $\begin{array}{l}4 \cdot 7 \\
5 \cdot 8 \\
6 \cdot 0\end{array}$ & $\begin{array}{l}0.3 \\
0.3 \\
0.5\end{array}$ & $\begin{array}{l}5 \cdot 8 \\
7 \cdot 2 \\
7 \cdot 6\end{array}$ \\
\hline 35 and over & $\begin{array}{l}\text { Chinese } \\
\text { Malay } \\
\text { Indian }\end{array}$ & $\begin{array}{r}5612 \\
1312 \\
390\end{array}$ & $\begin{array}{l}(6 \cdot 0) \\
(5 \cdot 9) \\
(4 \cdot 1)\end{array}$ & $\begin{array}{l}0.1 \\
- \\
-\end{array}$ & $\begin{array}{l}0.3 \\
0.3 \\
0.5\end{array}$ & $\begin{array}{l}1.1 \\
1.6 \\
0.5\end{array}$ & $\begin{array}{l}5 \cdot 1 \\
7 \cdot 4 \\
7 \cdot 4\end{array}$ & $\begin{array}{l}0.4 \\
0.3 \\
0.5\end{array}$ & $\begin{array}{l}6 \cdot 6 \\
9 \cdot 3 \\
8 \cdot 5\end{array}$ \\
\hline
\end{tabular}

- no births; 0 less than $0.1 \%$

Table 4 Low birthweight of live singletons by live birth order in the ethnic groups of Singapore, 1981-3

\begin{tabular}{|c|c|c|c|c|c|c|c|c|c|}
\hline \multirow[b]{2}{*}{$\begin{array}{l}\text { Live birth } \\
\text { Order }\end{array}$} & \multirow[b]{2}{*}{ Ethnic group } & \multicolumn{2}{|l|}{ Births } & \multicolumn{6}{|c|}{ Birthweight (g)\% } \\
\hline & & No. & $(\%)$ & $\begin{array}{l}\text { Under } \\
1000\end{array}$ & $\begin{array}{l}1000 \\
1499\end{array}$ & $\begin{array}{l}1500 \\
1999\end{array}$ & $\begin{array}{l}2000 \\
2499\end{array}$ & $\begin{array}{l}\text { Under } \\
1500\end{array}$ & $\begin{array}{l}\text { Under } \\
2500\end{array}$ \\
\hline 1 & $\begin{array}{l}\text { Chinese } \\
\text { Malay } \\
\text { Indian }\end{array}$ & $\begin{array}{r}42514 \\
9173 \\
4302\end{array}$ & $\begin{array}{l}(45 \cdot 6) \\
(41 \cdot 0) \\
(44 \cdot 8)\end{array}$ & $\begin{array}{l}0.1 \\
0.1 \\
0.1\end{array}$ & $\begin{array}{l}0.2 \\
0.5 \\
0.3\end{array}$ & $\begin{array}{l}0.7 \\
1.2 \\
1.4\end{array}$ & $\begin{array}{l}5 \cdot 8 \\
8 \cdot 7 \\
9 \cdot 6\end{array}$ & $\begin{array}{l}0.3 \\
0.5 \\
0.4\end{array}$ & $\begin{array}{r}6.8 \\
10.5 \\
11 \cdot 3\end{array}$ \\
\hline 2 & $\begin{array}{l}\text { Chinese } \\
\text { Malay } \\
\text { Indian }\end{array}$ & $\begin{array}{r}33248 \\
6690 \\
3322\end{array}$ & $\begin{array}{l}(35 \cdot 7) \\
(29 \cdot 9) \\
(34 \cdot 6)\end{array}$ & $\begin{array}{l}0.1 \\
0.2 \\
0.1\end{array}$ & $\begin{array}{l}0.2 \\
0.3 \\
0.6\end{array}$ & $\begin{array}{l}0.8 \\
1.0 \\
1.4\end{array}$ & $\begin{array}{l}4 \cdot 6 \\
5 \cdot 8 \\
7 \cdot 8\end{array}$ & $\begin{array}{l}0.3 \\
0.4 \\
0.7\end{array}$ & $\begin{array}{l}5 \cdot 7 \\
7 \cdot 2 \\
9.9\end{array}$ \\
\hline 3 & $\begin{array}{l}\text { Chinese } \\
\text { Malay } \\
\text { Indian }\end{array}$ & $\begin{array}{r}13114 \\
3734 \\
1376\end{array}$ & $\begin{array}{l}(14 \cdot 1) \\
(16 \cdot 7) \\
(14 \cdot 3)\end{array}$ & $\begin{array}{l}0.1 \\
- \\
0.1\end{array}$ & $\begin{array}{l}0.2 \\
0.3 \\
0.3\end{array}$ & $\begin{array}{l}0.8 \\
1.1 \\
0.6\end{array}$ & $\begin{array}{l}4 \cdot 0 \\
5 \cdot 0 \\
7 \cdot 3\end{array}$ & $\begin{array}{l}0.2 \\
0.3 \\
0.4\end{array}$ & $\begin{array}{l}5 \cdot 0 \\
6.3 \\
8.4\end{array}$ \\
\hline 4 & $\begin{array}{l}\text { Chinese } \\
\text { Malay } \\
\text { Indian }\end{array}$ & $\begin{array}{r}3267 \\
1525 \\
411\end{array}$ & $\begin{array}{l}(3 \cdot 5) \\
(6 \cdot 8) \\
(4 \cdot 3)\end{array}$ & $\begin{array}{l}0.1 \\
0 \cdot 1 \\
-\end{array}$ & $\begin{array}{l}0.2 \\
\overline{0.7}\end{array}$ & $\begin{array}{l}0.8 \\
1.0 \\
0.5\end{array}$ & $\begin{array}{l}4 \cdot 7 \\
6.0 \\
3.9\end{array}$ & $\begin{array}{l}0.3 \\
0.1 \\
0.7\end{array}$ & $\begin{array}{l}5 \cdot 7 \\
7 \cdot 1 \\
5 \cdot 1\end{array}$ \\
\hline 5 and over & $\begin{array}{l}\text { Chinese } \\
\text { Malay } \\
\text { Indian }\end{array}$ & $\begin{array}{r}1043 \\
1268 \\
202\end{array}$ & $\begin{array}{l}(1 \cdot 1) \\
(5 \cdot 7) \\
(2 \cdot 1)\end{array}$ & $\begin{array}{l}0.1 \\
- \\
-\end{array}$ & $\begin{array}{l}0.6 \\
0.4 \\
-\end{array}$ & $\begin{array}{l}1 \cdot 1 \\
1 \cdot 3 \\
-\end{array}$ & $\begin{array}{l}5 \cdot 3 \\
6 \cdot 2 \\
3 \cdot 5\end{array}$ & $\begin{array}{l}0.6 \\
0.5 \\
-\end{array}$ & $\begin{array}{l}6 \cdot 9 \\
8 \cdot 1 \\
3 \cdot 5\end{array}$ \\
\hline
\end{tabular}

- no births

proportion of low birthweight babies, then Malays, and then Chinese. However this does not hold for high parity women where in fact Indians have the lowest proportions.

\section{Discussion}

In this study all live singleton births in the three years 1981-3 have been examined. The World Health Organization has recommended that babies born before 37 completed weeks of gestation should be designated "pre-term" and those of birthweight less than $2500 \mathrm{~g}$ "low birthweight". 9

Table 2 shows that the proportion of babies that are pre-term are lowest in Chinese, then Indians and then Malays. Though not shown in the table, the proportions less than 28 weeks are $0.1 \%$ in Chinese and Indians, and $\mathbf{0 . 2 \%}$ in Malays. It should be noted that $0.1 \%$ was the lowest proportion (for Sweden and New Zealand) found in the 1973 study by the World Health Organization. ${ }^{10}$ However, for low birthweight, table 1 shows that the lowest rate is in Chinese, then 
Malays and then Indians. This pattern is consistent for all gestational periods (except pre-term when Malays have the lowest proportion, table 2). Of the low birthweight babies, the proportions that are premature are in fact lowest in Indians $(28.7 \%)$, then Chinese (33.5\%) and then Malays (35.2\%). The pattern also holds for maternal age groups (except the oldest women, table 3) and live birth order groups (except beyond 3, table 4). The reason for this difference with older and higher parity women is not clear, but tables 3 and 4 show that the numbers of Indian births in these categories are small. These findings then confirm those found in our previous study. ${ }^{5}$

There is unlikely to have been any measurement bias. For 1982, hospital deliveries accounted for $98.7 \%$ of births in Chinese, $97.8 \%$ in Indians, and $89.3 \%$ in Malays; only Malays had an appreciable proportion of home deliveries $(9 \cdot 1 \%)^{6}$ The policy in hospital is for a nurse to weigh the newborn baby, and there are three government (admitting the vast majority of patients) and four private hospitals in Singapore for maternity cases with no differential admission by ethnic group. Hence also medical care would not seem to have contributed to the birthweight differences.

There is a social class gradient in the incidence of low birthweight, ${ }^{11}$ though in the WHO study it was found not to be marked. ${ }^{12}$ But in Singapore Indians tend to occupy a socioeconomic position between that of Chinese and Malays illustrated by the postneonatal mortality rates per 1000 live births for 1982 of Chinese $2 \cdot 1$, Indians $2 \cdot 6$, and Malays $4 \cdot 4 .^{6}$ It is known that postneonatal mortality tends to be more affected by "social" than "medical" factors. ${ }^{13}$ This difference in socioeconomic position is also no doubt at least partly responsible for the differences in rates of prematurity by ethnic group (table 2). ${ }^{14}$ Hence in Singapore the social gradient is reflected in prematurity but not in low birthweight.

The social class gradient in low birthweight is considered to be at least partly explained by cigarette consumption during pregnancy. ${ }^{15}$ However the rates of smoking in adult women in Singapore are relatively low, and a survey in $1975^{16}$ found that it was in fact lowest in Indians (4.1\%), then Malays (4.5\%), and then Chinese (9.4\%). Hence smoking patterns do not account for the lack of social class gradient in birthweight. As discussed in our previous study, nutrition is not likely to be an explanation of the higher rate of low birthweight in Indians in relatively affluent Singapore. ${ }^{5}$ While the possibility of low birthweight being less common in some Chinese populations has been raised, ${ }^{4}$ it has been found here that the proportion of low birthweight babies in Indians is markedly higher than in Chinese and also higher than in Malays. Hence in Singapore there seems to be no explanation for the higher rate of low birthweight in Indian babies, and unless some unknown environmental factor is operating it must be considered to be at least partly of ethnic/genetic origin.

This is further confirmed by looking at neonatal mortality, of which low birthweight has been found to be the major determinant at both individual ${ }^{17}$ and population levels. ${ }^{18}$ For the three years 1981-3 combined, the neonatal mortality rates per 1000 live births were: Chinese $7 \cdot 1$, Indians $8 \cdot 7$, and Malays $9 \cdot 1 .^{6}$ In other words, though Indians have a greater proportion of low birthweight babies than Malays, they have a lower neonatal mortality rate. It is interesting that in a racially mixed community in Britain (though based on hospital deliveries and small numbers with possible bias), it was shown that while Indian babies were smaller than Caucasian and West Indian babies they had in fact the lowest perinatal mortality. ${ }^{19}$.

It seems therefore that these "small-for-dates" Indian babies are not necessarily less "mature". This would be fully clarified by looking at birthweightspecific neonatal mortality rates by ethnic group, but this would require the linking of birth and death certificates which is not yet available nationally in Singapore. However the data here certainly suggest that the internationally recognised weight of $2500 \mathrm{~g}$ used to define low birthweight should perhaps be revised downwards for Indian babies, particularly when international comparisons of the incidence of low birthweight are being made.

We are grateful to the Lee Foundation, States of Malaya for financial support and to Miss W Louis for typing the manuscript.

\section{References}

${ }^{1}$ Pharoah POD. Present patterns of disease in childhood. Proc Roy Soc Med 1976; 69: 335-8.

2 World Health Organization. Tech Rep Ser 1970, No.457.

3 World Health Organization. The incidence of low birth weight a critical review of available information. World Health Stat $Q$ 1980; 33: 197-224.

${ }^{4}$ Chalmers I. Shanghai. Lancet 1980; i: 137-9.

5 Hughes K, Tan NR, Lun KC. Low birthweight of live singletons in Singapore, 1967 to 1974. Int J Epidemiol 1984; 13: 465-71.

${ }^{6}$ Republic of Singapore. Report on Registration of births and deaths, various years. Singapore.

${ }^{7}$ World Health Organization. Social and biological effects on perinatal mortality: a WHO report volumes 1 and 2 . Saudi med J 1983; 4 supplement 1: 54-5. 
${ }^{8}$ World Health Organization. Manual of the international statistical classification of diseases, injuries and causes of death. Ninth Revision 1975, Volume 1, Geneva.

${ }^{9}$ Methodology of reporting and analysis of perinatal and maternal morbidity and mortality. Recommendations of World Health Organization expert committee. Bristol: WHO, 1972.

10 ibid, 58.

11 Oakley A, Macfarlane AJ, Chalmers I. Social class, stress and reproduction. In: Rees AR, Purcell H, eds. Disease and the environment. Chichester: John Wiley and Sons, $1982 ; 11-50$.

12 ibid, 90.

13 Pharoah POD, Morris JN. Postneonatal mortality. Epidemiol Rev 1979; 1: 170-83.

14 Ritchie K, McClure G. Prematurity. Lancet 1979; ii: 1227-9.
Kenneth Hughes, Nalla $R$ Tan, and Kwok-Chan Lun

${ }^{15}$ Rush D, Cassano P. Relationship of cigarette smoking and social class to birth weight and perinatal mortality among all births in Britain, 5-11 April 1970. J Epidemiol Community Health 1983; 37: 249-55.

${ }^{16}$ Lee HP. Smoking and blood pressure among adults in Singapore. Ann Acad Med Singapore 1980; 9: 416-20.

${ }^{17}$ Shah FK, Abbey H. Effects of some factors on neonatal and postneonatal mortality. Analysis by a binary multiple regression method. Milbank Mem Fund $Q$ 1971; 49: 33-57.

${ }^{18}$ Lee K, Paneth N, Gartner LM, Pearlman M. The very low-birth-weight rate: Principal predictor of neonatal mortality in industrialized populations. J Pediatrics 1980; 97: 759-64.

${ }^{19}$ Grundy MFB, Hood J, Newman GB. Birthweight standards in a community of mixed racial origin. $B r J$ Obstet Gynaecol 1978; 85: 481-6. 